\title{
L-carnitine mitigates bisphenol A-induced hepatic toxicity via activation of Nrf2 and inhibition of pro-inflammatory cytokine gene expression in rats
}

\author{
Mohamed A. Lebda*, Aml S. Hashem, Nabil M. Taha, Abd El-Wahab Mandour, \\ and Hanan A. Edres \\ Department of Biochemistry, Faculty of Veterinary Medicine, Alexandria University, Alexandria, Egypt
}

\begin{abstract}
LEBDA, M. A., A. S. HASHEM, N. M. TAHA, A. E.-W. MANDOUR, H. A. EDRES: L-carnitine mitigates bisphenol A-induced hepatic toxicity via activation of $\mathrm{Nrf} 2$ and inhibition of pro-inflammatory cytokine gene expression in rats. Vet. arhiv 90, 57-68, 2020.
\end{abstract}

ABSTRACT

Bisphenol, used in many polycarbonate plastics and epoxy resins industries, exerts toxic effects on mammalian organs. The mechanisms underlying bisphenol toxicity are well understood, however the chemoprevention effects of L-carnitine have not yet been recorded. This study aimed to explore the protective mechanism of L-carnitine against BPA-induced hepatotoxicity. Male rats were randomly distributed into 4 groups of 10 rats each: vehicle $(5 \mathrm{~mL}$ corn oil $/ \mathrm{kg}$ ), bisphenol (50 mg/kg b.w. orally), L-carnitine (500 mg/kg b.w. i/p), and L-carnitine bisphenol pre-treated groups. Bisphenol was dissolved in corn oil and gavaged for 70 consecutive days. Up-regulation of tumor necrosis factor (6.6-fold), and interleukin 6 (3.2-fold) mRNA transcript, along with suppression of nuclear factor erythroid 2-like 2 (0.4-fold), were recorded, following bisphenol administration. Subsequently, bisphenol provoked oxidative stress and attenuated the antioxidative molecules. Finally, hepatic dysfunction was assessed by elevated serum aminotransferases, alkaline phosphatase, lactate dehydrogenase, glutamyl transferase activities and ammonia levels, with the subsequent decline in serum albumin concentration, which confirmed the inflammatory cell infiltration and hydropic degeneration, and the impairment of lipid profile. Interestingly, co-administration of L-carnitine improved liver function and lipid profile, which was explained by the activation of nuclear factor erythroid 2-like 2 (1.5-fold) mRNA transcript, which augmented the antioxidant levels and suppressed oxidative stress, tumor necrosis factor (2.6fold), and interleukin 6 (1.5-fold) gene expression. In conclusion, L-carnitine exerted hepatoprotective activity against bisphenol toxicity via antioxidant and anti-inflammatory effects.

Key words: bisphenol A; L-carnitine; pro-inflammatory cytokines; hydropic degeneration; oxidative stress

\section{Introduction}

Bisphenol A (BPA), also known as 2,2-bis (4-hydroxyphenol) propane, has been widely used in the polycarbonate industries, plastic baby bottles, dental sealants, and the epoxy resin lining of beverage packaging and canned foods (VANDENBERG et al., 2009). BPA found in these products as a polymer is non-toxic, but when exposed to heat, UV light or a change in acidic or alkaline conditions, it converts to the monomer form and is released into foods and water, causing human exposure risk (TALSNESS et al., 2009). Following absorption from the intestinal tract, BPA metabolizes in the liver to form BPAglucuronide which is chemically inert, and by the time it is accumulated, due to delayed elimination,

\footnotetext{
*Corresponding author:

Mohamed A. Lebda, Department of Biochemistry, Faculty of Veterinary Medicine, Al-mandra Alexandria University 22758, Alexandria, Egypt, E-mail: lebdam1979@alexu.edu.eg; biochemistry232@yahoo.com
} 
there is an increase in the free BPA concentration in the blood (VÖLKEL et al., 2002). BPA has toxic effects on the liver. In tests, it induced hepatic lipid accumulation in zebra fish and human hepatocytes (MARTELLA et al., 2016), disrupted the liver morphology and increased liver transaminases and lactate dehydrogenase enzymes (KORKMAZ et al., 2010). Also, BPA caused induction of hepatic DNA damage (EID et al., 2015), and hepatic tumors (WEINHOUSE et al., 2014). The signaling pathway underlying BPA-induced toxicity in different organs, including the liver, is the induction of reactive oxygen species (ROS) formation, and pro-inflammatory cytokines, and the suppression of the antioxidant system (KABUTO et al., 2004).

L-carnitine (L- $\beta$-hydroxy- $\gamma$-N-trimethyl aminobutyrate), a natural product, can be synthesized in the body from methionine and lysine amino acids, and has a pivotal role in fatty acid metabolism. It has been suggested that it prevents oxidative stress-induced mitochondrial damage and apoptosis (ALEISA et al., 2008). L-carnitine acts as a scavenger of reactive oxygen species, inhibiting mitochondrial dysfunction in hepatocarcinogenic rats (CHANG et al., 2005). Also, THANGASAMY et al. (2009) reported the powerful antioxidant activity of carnitine through the inhibition of lipid peroxidation. Further, it was found that supplementation of L-carnitine to hypercholesterolemic rats reduced the hepatic level of thiobarbituric acid reactive substances (TBARS) and increased GSH concentration (KESKIN et al., 2015).

Nuclear factor erythroid-2-related factor-2 (Nrf2) is a nuclear transcriptional factor that binds DNA to the antioxidant response element and induces the transcription of the target genes encoding the antioxidant enzymes, thereby protecting cells from oxidative damage (WILLIAMSON et al., 2012). Also, ROS production can activate proinflammatory cytokine, tumor necrosis factor- $\alpha$ (TNF- $\alpha$ ) and interleukin-6 (IL-6) gene expression and release (DONG et al., 1998). On the other hand, the production of these cytokines can motivate ROS generation (BABBAR and CASERO, 2006). To our knowledge, data regarding the mechanics of the effect of carnitine on bisphenol toxicity are scarce.
Hence, the aim of the present study was to evaluate the chemo-protective and molecular effect of L-carnitine in long-term BPA-intoxicated rats, and the interplay of the antioxidant regulating master gene, Nrf2, oxidative stress and pro-inflammatory cytokine production.

\section{Materials and methods}

Chemicals and analytical reagents. Bisphenol $\mathrm{A}$ (BPA; 4, 4'-(propane-2, 2-diyl) diphenol; $\mathrm{C}_{15} \mathrm{H}_{16} \mathrm{O}_{2}$ ) was purchased from Sigma-Aldrich Co., (St. Louis, MO, USA). L- Carnitine ( $\beta$-hydroxy- $\gamma-\mathrm{N}$-trimethyl aminobutyric acid; $\mathrm{C}_{7} \mathrm{H}_{15} \mathrm{NO}_{3}$ ) was obtained from mepaco-medifood Co., Egypt. Malondialdehyde (MDA), reduced glutathione (GSH), and total antioxidant capacity (TAC), glutathione peroxidase (GPX), catalase (CAT), and superoxide dismutase (SOD) kits were obtained from Bio diagnostic Co., Egypt. Biodiagnostic Kits of alanine aminotransferase (ALT), aspartate aminotransferase (AST), $\gamma$-glutamyl transferase $(\gamma$-GT), alkaline phosphatase (ALP), lactate dehydrogenase (LDH), ammonia, total protein, cholesterol, triacylglycerol (TAG), and low density lipoprotein cholesterol (LDL-c) were purchased from Vitro Scient Co., Egypt. The GF-1Total RNA Extraction Kit was delivered from Vivantis Co. Subang Jaya Malaysia. The One-step Rotor-Gene SYBR Green RT-PCR Master Mix was obtained from Qiagen, USA.

Animal and experimental design. Forty adult male albino rats, 3 months old, weighing $180 \pm$ $20 \mathrm{~g}$ were kindly provided by the Biochemistry Department, Faculty of Veterinary Medicine, Alexandria University. The rats were housed in stainless steel, wire bottom cages, with $14 \mathrm{hr}$ light and $10 \mathrm{hr}$. dark, and adequate ventilation. They were fed standard diet pellets and allowed food and water ad libitum for an acclimation period of two weeks. The experiment was carried out according to the National Institute of Health guide for the care and use of Laboratory animals (NIH Publications No. 8023, revised 1978) and approved by the Ethics Committee at the Faculty of Veterinary Medicine, Alexandria University. The rats were randomly divided into 4 groups of 10 rats each, as following; the control received $5 \mathrm{~mL} / \mathrm{kg}$ body weight vehicle (corn oil) by oral gavage daily, the BPA group was 
treated orally with bisphenol at a dose of $50 \mathrm{mg} /$ $\mathrm{kg}$ body weight, dissolved in $5 \mathrm{~mL}$ corn oil $\mathrm{kg} / \mathrm{b}$.w. for 70 days for induction of hepatotoxicity, the L-carnitine-treated rats were administered $500 \mathrm{mg} /$ $\mathrm{kg} /$ day of L-carnitine via intraperitoneal injection, and the L-carnitine + BPA group was administered BPA and L-carnitine at the same doses and using the same route of administration. The BPA dose was chosen on the basis of previous experimental findings, toxicokinetics, the route of administration, and metabolic capacity (YILDIZ and BARLAS, 2013).

Blood and tissue collection. $24 \mathrm{hr}$ after the last doses, the rats were anesthetized using an $\mathrm{i} / \mathrm{p}$ injection of ketamine/xylazine, and blood samples were obtained from the retro-orbital sinus of the eye using heparinized capillary tubes, into two types of clean tubes, according to HOFF and RLAGT, (2000), one without anticoagulant for separation of sera, and the other containing anticoagulant for separation of plasma. Immediately after blood collection, the rats were then euthanized by decapitation under the previously specified anesthesia, according to the AVMA guidelines for euthanasia of animals, 2013 edition, and their livers were rapidly excised and divided into three parts; one part was preserved in $10 \%$ neutral buffered formalin for histological studies, the second was kept at $-80{ }^{\circ} \mathrm{C}$ for molecular examinations. The third part was homogenized using a glass homogenizer with ice-cooled saline to prepare $25 \%$ $w / v$ homogenate. The homogenate was divided into two aliquots. The first one was deproteinized with ice-cooled $12 \%$ trichloroacetic acid and the supernatant obtained, after centrifugation at $1000 \mathrm{~g}$, was used for estimation of the GSH content. The second aliquot was centrifuged at $1000 \mathrm{~g}$ and the resultant supernatant was used for estimation of levels of MDA, TAC, and antioxidant enzymes.

Serum and plasma biochemical analyses. Liver functions were assessed by measuring the serum enzymatic biomarkers, ALT, AST, ALP, $\gamma$-GT, and $\mathrm{LDH}$ activities, along with plasma ammonia levels, according to the manufacturer's instructions. Measurement of serum total protein, albumin, and lipid profile, TAG, total cholesterol, HDL-c, LDL-c, and VLDL-c were also performed according the manufacturer's instructions.

Oxidative/antioxidative parameters. Hepatic GSH levels were determined as described by the method of SEDLAK and LINDSAY (1968) using Ellman's reagent, and expressed as nmol/g tissue. The level of the lipid peroxidation end products in the liver, on the basis of measurement of thiobarbituric acid-reactive substances (TBARS), was also evaluated according to the method described by OHKAWA et al. (1979), and expressed as $\mathrm{nmol} / \mathrm{g}$ tissue. TAC in the liver was measured as described by KORACEVIC et al. (2001), and expressed as $\mathrm{mmol} / \mathrm{g}$ tissue. The activities of enzymatic antioxidants were assayed and expressed as U/g tissue: CAT (ABEI, 1984), GPX (PAGLIA and VALENTINE, 1967), and SOD (KAKKAR et al., 1984).

qRT-PCR of hepatic Nrf2, TNF- $\alpha$, and IL-6 expression. Hepatic total RNA was isolated using a GF-1 Total RNA Extraction Kit (Vivantis, Malaysia) according to the manufacturer's instructions. The yield of total RNA obtained was determined using a Nano Drop 2000 spectrophotometer (Thermo Fischer Scientific, USA). One step Rotor-Gene SYBR Green RT-PCR Master Mix (Qiagen, USA) was performed to estimate the relative quantitative determination of the gene expressions of $\mathrm{Nrf} 2$, TNF- $\alpha$, and IL- 6 mRNA level. Briefly, $12.5 \mu \mathrm{L}$ of Rotor-Gene SYBR Green RT-PCR Master Mix, $1 \mu \mathrm{L}$ of forward primer, $1 \mu \mathrm{L}$ of reverse primer (primer sequences are reported in Table 1), 0.25 $\mu \mathrm{L}$ Rotor Gene RT mix, $2 \mu \mathrm{L}$ RNA sample were combined, and the reaction completed up to 25 $\mu \mathrm{L}$ with nuclease free water. The real time PCR device was programmed at $55{ }^{\circ} \mathrm{C}$ for $10 \mathrm{~min}$ for cDNA synthesis, followed by $95{ }^{\circ} \mathrm{C}$ for $5 \mathrm{~min}$ for inactivation of the reverse transcriptase enzyme. A total of 40 cycles were performed as follows: 95 ${ }^{\circ} \mathrm{C} / 15 \mathrm{~s}, 55{ }^{\circ} \mathrm{C} / 15 \mathrm{~s}, 60{ }^{\circ} \mathrm{C} / 15 \mathrm{~s}$, followed by $60{ }^{\circ} \mathrm{C}$ for $10 \mathrm{~min}$. The relative expression was quantified relative to the expression of the reference gene (GAPDH) in the same sample, by calculating and normalizing the threshold cycle $(\mathrm{Ct})$ values of the target genes to that of GAPDH, using the $\Delta \Delta \mathrm{Ct}$ method. 
Table 1 Primer sequence used for qRT-PCR

\begin{tabular}{|l|l|l|l|}
\hline Gene symbol & Gene description & Gene bank & Sequence \\
\hline Nrf2 & $\begin{array}{l}\text { Nuclear factor, } \\
\text { erythroid 2-like 2 }\end{array}$ & NC_005102.4 & $\begin{array}{l}\text { F: 5'-TCTCCTCGCTGGAAAAAGAA-3' } \\
\text { R: 5'-TCTCCTCGCTGGAAAAAGAA-3' }\end{array}$ \\
\hline TNF- $\alpha$ & $\begin{array}{l}\text { Tumor necrosis } \\
\text { factor alpha }\end{array}$ & NC_005119.4 & $\begin{array}{l}\text { F: 5'-CAGGTTCTCTTCAAGGGACAAG-3' } \\
\text { R: 5'-GCAGAGAGGAGGTTGACTTTC-3' }\end{array}$ \\
\hline IL6 & Interleukin 6 & NC_005103.4 & $\begin{array}{l}\text { F: 5'-GCAGAGAGGAGGTTGACTTTC-3' } \\
\text { R: 5'-GACAGGTCTGTTGGGAGTGGTATC-3' }\end{array}$ \\
\hline gapdh* & $\begin{array}{l}\text { Glyceraldehyde- } \\
\text { 3-phosphate } \\
\text { dehydrogenase }\end{array}$ & NC_005103.4 & $\begin{array}{l}\text { F: 5'-GGGTGTGAACCACGAGAAATA-3' } \\
\text { R: 5'-AGTTGTCATGGATGACCTTGG-3' }\end{array}$ \\
\hline
\end{tabular}

*Housekeeping gene

Histopathological analyses. After necropsy, small liver specimens were collected from all the treated rats, and rapidly fixed in $10 \%$ neutral formalin for $24 \mathrm{hrs}$. After fixation, tissue specimens were processed using the conventional paraffin embedding technique. $5 \mu \mathrm{m}$ thick sections were obtained from paraffin blocks, stained with hematoxylin and eosin, and examined under a light microscope (CULLING et al., 1985).

Statistical analysis. The data are expressed as the mean \pm standard error of the mean (SEM). The data were analyzed using one-way analysis of variance (ANOVA), followed by post hoc multiple comparisons and Tukey's HSD test. All data were analyzed using the SPSS statistical package version 22.0 for Windows (IBM, Armonk, NY, USA). The level of significance was set at $\mathrm{P}<0.05$.

\section{Results}

Serum enzymatic biomarkers for assessment of liver function. The data presented in Table 2 reveal that rats intoxicated with BPA $50 \mathrm{mg} / \mathrm{Kg}$ bw had a significant increase in serum ALT $(46.9 \pm 0.96$ $\mathrm{U} / \mathrm{L}), \operatorname{AST}(276 \pm 5.43 \mathrm{U} / \mathrm{L}), \operatorname{ALP}(729 \pm 15.4$ $\mathrm{U} / \mathrm{L}), \gamma-\mathrm{GT}(5.39 \pm 0.44 \mathrm{U} / \mathrm{L})$, and LDH $(2653 \pm$ 89.1 U/L) activities when compared to the control. However, L-carnitine treatment non-significantly increased serum AST $(217 \pm 3.62 \mathrm{U} / \mathrm{L}), \operatorname{ALP}(562 \pm$ $35.5 \mathrm{U} / \mathrm{L})$, GGT $(3.36 \pm 0.3 \mathrm{U} / \mathrm{L})$, and LDH (2195 $\pm 53.3 \mathrm{U} / \mathrm{L})$ activities, with a significant increase in serum ALT $(39.5 \pm 1.02 \mathrm{U} / \mathrm{L})$ activity when compared to the control. Interestingly, treatment of BPA-intoxicated rats with L-carnitine significantly $(\mathrm{P}<0.05)$ decreased serum AST $(245 \pm 13.73 \mathrm{U} / \mathrm{L})$, and ALP $(647 \pm 28.33 \mathrm{U} / \mathrm{L})$ activities, with a nonsignificant decrease in serum ALT $(45.4 \pm 1.58 \mathrm{U} / \mathrm{L})$, $\operatorname{GGT}(5.19 \pm 0.48 \mathrm{U} / \mathrm{L})$, and LDH $(2447 \pm 132 \mathrm{U} / \mathrm{L})$ activities when compared to the corresponding ones in the BPA-challenged rats.

Serum protein pattern and plasma ammonia level. Plasma ammonia $(214 \pm 5.73 \mu \mathrm{g} / \mathrm{dL})$ levels increased significantly $(\mathrm{P}<0.05)$, with a significant

Table 2. Serum hepatic enzyme biomarkers in rats treated with Bisphenol-A and L-carnitine

\begin{tabular}{|l|c|c|c|c|}
\hline \multirow{2}{*}{ Parameter } & \multicolumn{3}{|c|}{ Group } \\
\cline { 2 - 5 } & Control & Bisphenol & Carnitine & Bisphenol + Carnitine \\
\hline ALT U/L & $34.8 \pm 1.11^{\mathrm{c}}$ & $46.9 \pm 0.96^{\mathrm{a}}$ & $39.5 \pm 1.02^{\mathrm{b}}$ & $45.4 \pm 1.58^{\mathrm{a}}$ \\
\hline AST U/L & $197 \pm 7.98^{\mathrm{c}}$ & $276 \pm 5.43^{\mathrm{a}}$ & $217 \pm 3.62^{\mathrm{c}}$ & $245 \pm 13.73^{\mathrm{b}}$ \\
\hline ALP U/L & $565 \pm 12.3^{\mathrm{c}}$ & $729 \pm 15.4^{\mathrm{a}}$ & $562 \pm 35.5^{\mathrm{c}}$ & $647 \pm 28.33^{\mathrm{b}}$ \\
\hline GGT U/L & $2.45 \pm 0.30^{\mathrm{b}}$ & $5.39 \pm 0.44^{\mathrm{a}}$ & $3.36 \pm 0.30^{\mathrm{b}}$ & $5.19 \pm 0.48^{\mathrm{a}}$ \\
\hline LDH U/L & $1986 \pm 127^{\mathrm{c}}$ & $2653 \pm 89.1^{\mathrm{a}}$ & $2195 \pm 53.3^{\mathrm{bc}}$ & $2447 \pm 132^{\mathrm{ab}}$ \\
\hline
\end{tabular}

Values are means \pm SE. Means without a common superscript in a row differ significantly $(\mathrm{P}<0.05)$. ALT - alanine transaminase; AST - aspartate transaminase; ALP - alkaline phosphatase; GGT - gamma glutamyl transferase; LDH - lactate dehydrogenase 
Table 3. Effect of bisphenol and /or carnitine on serum protein patterns and plasma ammonia levels in rats

\begin{tabular}{|l|c|c|c|c|}
\hline \multirow{2}{*}{ Parameter } & \multicolumn{4}{|c|}{ Group } \\
\cline { 2 - 5 } & Control & Bisphenol & Carnitine & Bisphenol + Carnitine \\
\hline Total protein, g/dL & $6.01 \pm 0.26^{\text {bc }}$ & $5.39 \pm 0.11^{\mathrm{c}}$ & $6.84 \pm 0.29^{\mathrm{a}}$ & $6.46 \pm 0.18^{\mathrm{ab}}$ \\
\hline Albumin, g/dL & $3.18 \pm 0.16^{\mathrm{a}}$ & $2.44 \pm 0.15^{\mathrm{b}}$ & $2.78 \pm 0.08^{\mathrm{b}}$ & $2.61 \pm 0.14^{\mathrm{b}}$ \\
\hline Globulin, g/dL & $2.83 \pm 0.27^{\mathrm{b}}$ & $2.95 \pm 0.15^{\mathrm{b}}$ & $4.06 \pm 0.24^{\mathrm{a}}$ & $3.86 \pm 0.27^{\mathrm{a}}$ \\
\hline A/G ratio & $1.23 \pm 0.17^{\mathrm{a}}$ & $0.86 \pm 0.09^{\mathrm{b}}$ & $0.70 \pm 0.03^{\mathrm{b}}$ & $0.72 \pm 0.09^{\mathrm{b}}$ \\
\hline Ammonia, $\mu \mathrm{g} / \mathrm{dL}$ & $197 \pm 4.53^{\mathrm{b}}$ & $214 \pm 5.73^{\mathrm{a}}$ & $192 \pm 3.58^{\mathrm{b}}$ & $200 \pm 3.03^{\mathrm{b}}$ \\
\hline
\end{tabular}

Values are means \pm SE. Means without a common superscript in a row differ significantly $(\mathrm{P}<0.05)$. A/G ratio - albumin to globulin ratio

Table 4. Serum lipid profile in rats treated with Bisphenol-A and L- carnitine

\begin{tabular}{|l|c|c|c|c|}
\hline \multirow{2}{*}{ Parameter } & \multicolumn{4}{|c|}{ Group } \\
\cline { 2 - 5 } & Control & Bisphenol & Carnitine & Bisphenol + Carnitine \\
\hline Cholesterol, mg/dL & $80.8 \pm 1.56^{\mathbf{b}}$ & $91.4 \pm 3.06^{\mathbf{a}}$ & $85.1 \pm 3.55^{\mathbf{b}}$ & $83.3 \pm 3.39^{\mathbf{b}}$ \\
\hline TAG, mg/dL & $147 \pm 1.17^{\mathbf{c}}$ & $168 \pm 1.41^{\mathbf{a}}$ & $156 \pm 2.07^{\mathbf{b}}$ & $161 \pm 2.11^{\mathbf{b}}$ \\
\hline HDL-c, mg/dL & $35.5 \pm 1.28^{\mathbf{a}}$ & $20.1 \pm 1.19^{\mathbf{c}}$ & $38.4 \pm 1.04^{\mathbf{a}}$ & $32.0 \pm 1.22^{\mathbf{b}}$ \\
\hline LDL-c, mg/dL & $15.9 \pm 2.61^{\mathbf{b}}$ & $27.8 \pm 2.53^{\mathbf{a}}$ & $15.6 \pm 2.81^{\mathbf{b}}$ & $19.2 \pm 3.64^{\mathbf{b}}$ \\
\hline VLDL-c, mg/dL & $29.31 \pm 0.23^{\mathbf{c}}$ & $33.5 \pm 0.28^{\mathbf{a}}$ & $31.2 \pm 0.41^{\mathbf{b}}$ & $32.1 \pm 0.42^{\mathbf{b}}$ \\
\hline
\end{tabular}

Values are means \pm SE. Means without a common superscript in a row differ significantly $(\mathrm{P}<0.05)$. TAG - triacylglycerol; HDL-chigh density lipoprotein cholesterol; LDL-c - low density lipoprotein cholesterol; VLDL-c - very low density lipoprotein cholesterol

Table 5. Hepatic MDA, TAC, and GSH levels in rats treated Bisphenol-A and L-carnitine

\begin{tabular}{|l|c|c|c|c|}
\hline \multirow{2}{*}{} & \multicolumn{4}{|c|}{ Group } \\
\cline { 2 - 5 } & Control & Bisphenol & Carnitine & Bisphenol + Carnitine \\
\hline MDA, nmol/g tissue & $107 \pm 4.01^{\mathbf{c}}$ & $146 \pm 3.86^{\mathrm{a}}$ & $100 \pm 2.19^{\mathrm{c}}$ & $134 \pm 1.67^{\mathbf{b}}$ \\
\hline TAC, mmol/g tissue & $14.9 \pm 0.89^{\mathrm{a}}$ & $9.75 \pm 0.43^{\mathrm{c}}$ & $15.0 \pm 0.97^{\mathrm{a}}$ & $12.3 \pm 0.62^{\mathbf{b}}$ \\
\hline GSH, nmol/g tissue & $54.3 \pm 2.81^{\mathrm{a}}$ & $39.1 \pm 1.62^{\mathrm{b}}$ & $44.6 \pm 2.64^{\mathrm{b}}$ & $42.9 \pm 2.46^{\mathbf{b}}$ \\
\hline GPX, U/g tissue & $23.17 \pm 0.23$ & $11.08 \pm 0.25$ & $35.21 \pm 0.22$ & $20.04 \pm 0.55$ \\
\hline CAT, U/g tissue & $512.12 \pm 3.16$ & $121.72 \pm 2.3$ & $501.5 \pm 3.11$ & $331.37 \pm 2.6$ \\
\hline SOD, U/g tissue & $126.23 \pm 1.18$ & $73.92 \pm 1.1$ & $147.12 \pm 1.2$ & $121.13 \pm 1.2$ \\
\hline
\end{tabular}

Values are means \pm SE. Means without a common superscript in a row differ significantly $(\mathrm{P}<0.05)$. MDA - malondialdehyde; TACtotal antioxidant capacity; GSH - reduced glutathione; GPX - glutathione peroxidase; CAT - catalase; SOD - superoxide dismutase

decrease in serum levels of albumin $(2.44 \pm 0.15$ $\mathrm{g} / \mathrm{dL})$, and $\mathrm{A} / \mathrm{G}$ ratio $(0.86 \pm 0.09)$, and a nonsignificant decrease in serum total protein $(5.39 \pm$ $0.11 \mathrm{~g} / \mathrm{dL}$ ) concentration in the BPA-treated group, as compared to the control. Meanwhile, L-carnitine supplementation significantly increased serum total protein $(6.84 \pm 0.29 \mathrm{~g} / \mathrm{dL})$, and globulin $(4.06 \pm 0.24$ $\mathrm{g} / \mathrm{dL}$ ) concentrations, with a significant decrease in serum albumin $(2.78 \pm 0.08 \mathrm{~g} / \mathrm{dL})$ levels, and A/G ratio $(0.70 \pm 0.03)$, along with a non-significant change in serum ammonia levels $(192 \pm 3.58 \mu \mathrm{g} /$ dL) compared to the control rats. Additionally, BPA-intoxicated rats treated with carnitine showed a significant increase in serum total protein $(6.46 \pm$ $0.18 \mathrm{~g} / \mathrm{dL})$, and globulin $(3.86 \pm 0.27 \mathrm{~g} / \mathrm{dL})$, with a significant decrease in serum ammonia levels (200 $\pm 3.03 \mu \mathrm{g} / \mathrm{dL}$ ) and non-significant changes in serum albumin level and $\mathrm{A} / \mathrm{G}$ ratio, when compared to the respective values in BPA-treated rats (Table 3). 


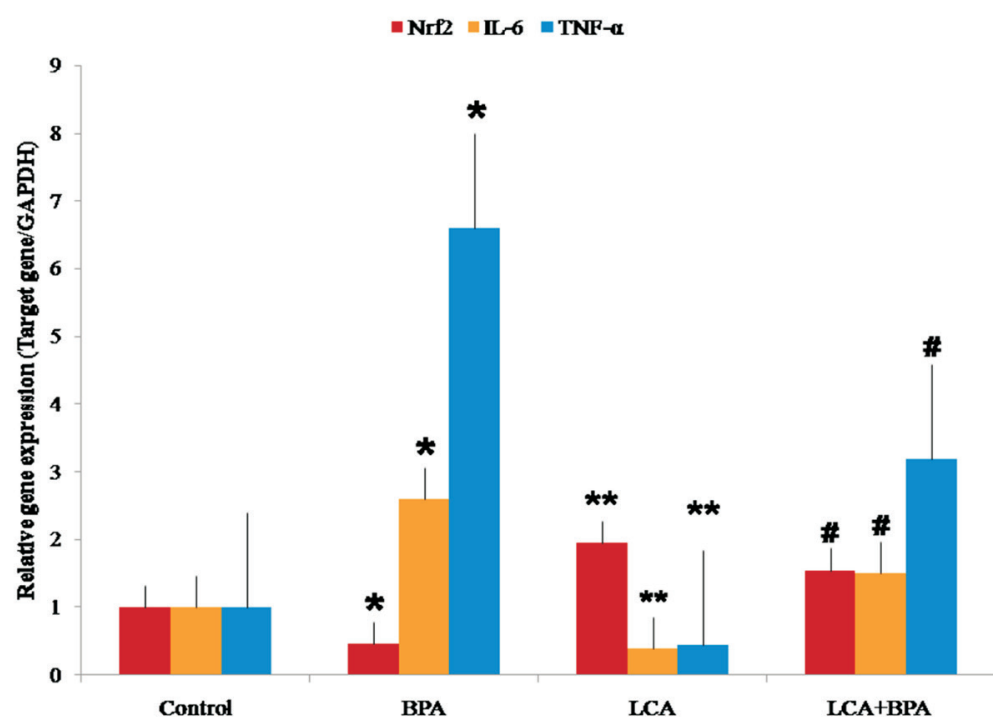

Fig. 1. Fold change of hepatic Nrf2, TNF- $\alpha$, and IL-6 mRNA transcript. *Significant differ from control at $\mathrm{P}<0.01$; **Significant differ from control at $\mathrm{P}<0.01$; \# significant differ bisphenol group at $\mathrm{P}<0.05$. BPA; bisphenol, LCA; L-carnitine, LCA+BPA; L-carnitine pretreated bisphenol group, Nrf2; nuclear factor erythroid 2-like 2, TNF- $\alpha$; tumor necrosis factor alpha, IL-6; interleukin 6 .
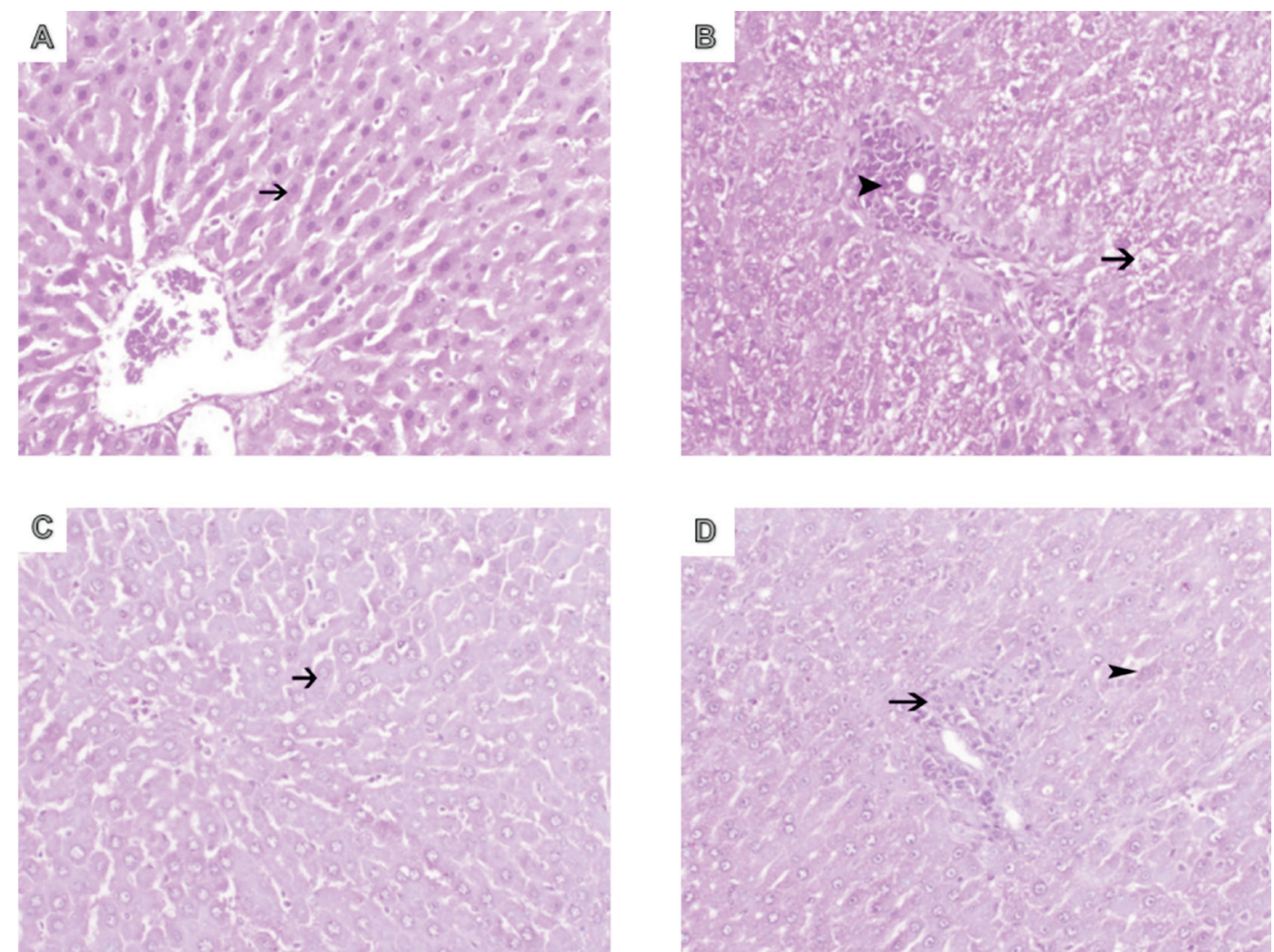

Fig. 2. Photomicrograph of hepatic tissue stained with H\&E $200 \mathrm{~nm}$. (A); Normal hepatic architecture (arrow), (B); Bisphenol-treated rats showed severe hydropic degeneration (arrow) and inflammatory cell infiltration (arrow head), (C); L-carnitine supplemented group revealed normal pathology (arrow), and (D) L-carnitine pretreated bisphenol group showed single cell necrosis (arrow head) and mild periportal mononuclear cell infiltrations (arrow). 
Serum lipid profile. Serum total cholesterol $(91.4 \pm 3.06 \mathrm{mg} / \mathrm{dL})$, TAG $(168 \pm 1.41 \mathrm{mg} / \mathrm{dL})$, LDL-c $(27.8 \pm 2.53 \mathrm{mg} / \mathrm{dL})$, and VLDL-c $(33.5 \pm$ $0.28 \mathrm{mg} / \mathrm{dL}$ ) increased significantly while serum HDL-c $(17.1 \pm 1.19 \mathrm{mg} / \mathrm{dL})$ was significantly lower $(\mathrm{P}<0.05)$ in BSA-challenged rats, as compared to the control values (Table 4). Treatment of BSAintoxicated rats with L-carnitine significantly increased serum total cholesterol, and HDL-c levels, with decreased serum TAG, and VLDL-c levels, and without change in serum LDL-c levels, when compared to the BSA-treated rats.

Oxidative/antioxidative profile. Bisphenol A induced oxidative stress, as indicated by the significant increase in hepatic MDA levels (146 $\pm 3.86 \mathrm{nmol} / \mathrm{g}$ tissue), with attenuation of TAC $(9.75 \pm 0.43 \mathrm{mM} / \mathrm{g}$ tissue $), \mathrm{GSH}(39.1 \pm 1.62 \mathrm{mg} /$ $\mathrm{g}$ tissue), GPX (- 52\%), CAT (- 66\%), and SOD ($41 \%$ ) when compared to the control. Meanwhile, L-carnitine significantly $(\mathrm{P}<0.05)$ decreased the concentration of hepatic MDA $(134 \pm 1.67 \mathrm{nmol} / \mathrm{g}$ tissue), increased the TAC level $(12.3 \pm 0.62 \mathrm{mM} / \mathrm{g}$ tissue), GPX $(+80 \%)$, CAT $(+172 \%)$, and SOD (+ $64 \%$ ) with an insignificant increase in hepatic GSH levels $(42.9 \pm 2.46 \mathrm{mg} / \mathrm{g}$ tissue) compared to those in BPA-intoxicated rats (Table 5).

Hepatic Nrf2, TNF- $\alpha$, and IL-6 mRNA transcript. Nrf2 mRNA transcript expression in hepatic tissue in the BPA-treated group was significantly lower(-50\%) as compared to the control. However, treatment of rats with L-carnitine significantly increased Nrf2 mRNA transcript (1.8-fold) in the liver when compared to the control. Interestingly, co-administration of BPA with L-carnitine significantly increased (1.5-fold) the expression of Nrf2 mRNA transcript in comparison with BSAintoxicated rats (Fig. 1).

Conversely, BPA significantly activated the gene expression of TNF- $\alpha$ (6.6-fold), and IL-6 (2.6-fold) in relation to the control. Meanwhile, L-carnitine significantly reduced TNF- $\alpha$ (3.2-fold), and Il-6 (1.5-fold) mRNA transcript as compared to BPAchallenged rats, indicating its anti-inflammatory activity.

Histopathological findings. Normal hepatocytes arranged in cords around the central vein (arrow) were observed in the control rats (Fig. 2A)
However, the hepatic cells of the BSA-treated rats showed mononuclear inflammatory cell infiltration (arrowhead) in the periportal area, associated with severe hydropic degeneration (arrow) of the hepatocytes (Fig. 2B). On the other hand, the L-carnitine-treated group showed normal hepatic architecture (arrow) (Fig. 2C). However, the livers of the BPA-challenged rats showing single cell necrosis (arrowhead) associated with mild periportal mononuclear inflammatory cell infiltration (arrow) (Fig. 2D).

\section{Discussion}

The present study showed the hepatic alterations induced by long-term exposure to high doses of BPA, by means of analysis of liver enzymatic activities, lipid profile, oxidant/antioxidant biomarkers, and gene expression of Nrf2. Furthermore, we studied whether L-carnitine administration could minimize the adverse effects of BPA. This study revealed that BPA induced liver damage, represented by elevated liver enzyme: (ALT, AST, ALP, LDH and $\gamma$-GT), and ammonia levels, with a decline in the serum albumin level, confirmed by our histopathological findings. Our results coincided with other previous studies based on the elevation of serum ALT, AST, ALP activities, and bilirubin level, along with the decline in the serum total protein and albumin levels in BPA-challenged rats (EZEONU et al., 2015). Also, VAHDATI HASSANI et al. (2017) demonstrated BSA-induced liver injuries through elevated serum AST, and LDH enzymes, with periportal inflammation and necrosis. Leakage of the liver enzymes AST, and LDH as the result of disruption of the hepatocellular plasma membrane, may be a biomarker for inflammatory and necrotic injuries (GIANNINI et al., 2005). These findings were confirmed recently by KAMEL et al. (2018), who found that BPA induced hepatic necrotic changes, vacuolar degeneration, sinusoid dilatation, and nuclei pyknosis. Further, fatty degeneration, inflammatory cell infiltration, vacuolar degeneration, and congestion of blood vessels are considered the main characteristics of BPA toxicity, besides biochemical elevation of serum AST, ALT, and bilirubin concentration (ABDEL SAMIE et al., 2017). L-carnitine intake improved the liver function and histopathological findings compared to the BPA group. Parallel to this 
result, CAYIR et al. (2009) showed that L-carnitine obviously attenuated sinusoidal dilatation, leukocyte infiltration, and hepatocyte cytoplasmic changes in cisplatin-treated rats. Also, L-carnitine co-treatment with methotrexate produced mild congestion, vacuolation of hepatocytes, and decreased the apoptotic cells, and serum ALT and AST enzymatic activities (TOUSSON et al., 2014). Furthermore, rats fed a high cholesterol diet and treated with L-carnitine showed a significant decline in serum ALT, AST, ALP, and GGT enzymatic activities, supporting the notion of the prevention of hepatic injuries and enzyme leak (KESKIN, 2015). The hepatoprotective role of L-carnitine may be attributed to its direct antioxidant effect, or to the augmentation of endogenous antioxidative defenses.

The present study suggests that BPA induces lipid metabolism disorders, since the serum TAG, total cholesterol, VLDL-c, and LDL-c increased, while serum HDL-C levels decreased, indicating hepatic lipid accumulation and liver damage. Increased serum triacylglycerol, fatty acid synthesis, and glucose concentration were reported with different doses of BPA in mice (MARMUGI et al., 2012). Meanwhile, ABDEL-WAHAB, (2014) showed the elevation of serum TAG, cholesterol, and LDL-c levels, along with HDL-c level decline following 4 weeks of BPA administration. MOGHADDAM et al. (2015) found high levels of serum TAG, total cholesterol, LDL-c and glucose and a low level of HDL-c in BSA-intoxicated rats. In this study, L-carnitine protected the liver from the damaging effects of BPA, via improvement of the serum lipid profile. This result was in agreement with MALAGUARNERA et al. (2010), who found that L-carnitine ameliorated the blood glucose, TAG, cholesterol, and lipoprotein concentrations in NASH patients. Also, pemphigus valugaris patients had low levels of serum total cholesterol, TAG, and LDL-c without any change in HDL-c level, following L-carnitine administration (MOHAMMADI et al., 2018). The reduction in the serum LDL-c concentration may be attributed to the enhancement of LDL receptor expression by L-carnitine (YOUSEFINEJAD et al., 2015). Moreover, L-carnitine reduced the serum TAG, and VLDL-c levels, interceded through augmentation of the peroxisome proliferator activated receptor
(PPAR- $\alpha$ ), and carnitine palmitoyltransferase-1 (CPT-1) gene expression, resulting in the activation of fatty acid oxidation (YOUSEFINEJAD et al., 2018). It was reported recently that L-carnitine supplementation reduced the serum total cholesterol and TAG concentration and muscle oxidative stress via regulation of PPAR- $\gamma$ mRNA expression in chronically exercised rats (PALA et al. 2018).

It has been noted that BPA-induced hepatotoxicity is mediated through the induction of oxidative stress, which is the primary cause of cell membrane injuries and leakage of marker enzymes (MOON et al., 2012), lipid accumulation, and hepatic inflammation (HUC et al., 2012). Our results revealed the accumulation of hepatic lipid byproducts, MDA, besides low GSH and TAC concentrations, and antioxidant enzymatic activities coinciding with down-regulation of Nrf2 mRNA and up-regulation of TNF- $\alpha$, and IL-6 gene expression. BPA increased the expression and serum levels of TNF- $\alpha$, and IL- 6 in HepG2 cells, suggesting the contribution of these cytokines to oxidative stress induction and mitochondrial dysfunction (MOON et al., 2012). These results were in parallel with those of KAZEMI et al. (2017) who proved the link between induction of oxidative stress and BPA accumulation. KORKMAZ et al. (2010) suggested that BPA-induced liver injuries may be attributed to an oxidative/antioxidative imbalance. The lipophilic property of BPA was incriminated in the induction of oxidative stress, which reacts with the lipophilic cell membrane, instigating $\mathrm{OH}$ radical formation, and creating lipid peroxidation (SUTHAR et al., 2014). The explanation of low GSH levels in the BPA-treated group may be attributed to the exhaustion of GSH for ROS scavenging. This result coincides with HASSAN et al. (2012), who reported that BPA resulted in attenuation of GSH levels and SOD activity. Recently, KAMEL et al. (2018) recorded elevated hepatic MDA levels, along with a significant decrease in SOD, and GSH levels in BSA-treated rats. We suggest that BPAinduced pro-inflammatory cytokines associated with the generation of oxidative stress, along with the suppression of Nrf2 and depletion of enzymatic and non-enzymatic antioxidants, are the central mechanism contributing to BPA-induced hepatic damage. Our hypothesis correlates with 
the results of WAHBY et al. (2017) who ascribed the hepatic damage caused by BPA to the induction of TNF- $\alpha$, resulting in an increase in oxidative stress and a decline in GSH levels and antioxidant enzymatic activities. The principal mechanism of the protective effect of L-carnitine against BPA-induced hepatotoxicity could be mediated through the induction of endogenous antioxidative molecules. The hepatoprotective activity of some natural products is mediated through free radical scavenging activity, or via induction of Nrf2augmented antioxidant gene expression (ALRASHEED et al., 2016). The protective effect of L-carnitine against bisphenol toxicity is due to its antioxidant and anti-inflammatory activities (MANSOUR, 2006). L-carnitine has the ability to inhibit the inflammatory signaling pathway in some hepatic inflammatory conditions and fibrosis (ANNADURAI et al., 2011). The anti-inflammatory activity of L-carnitine could be attributed to the attenuation of NF-KB, the principal activator of most pro-inflammatory cytokines as TNF- $\alpha$ and interleukins. This explanation coincides with the recent findings of BODAGHI-NAMILEH et al. (2018) who mentioned that co-administration of carnitine with arsenic, down-regulated NF-KB expression, suggesting the anti-inflammatory activity of carnitine and suppression of oxidative stress. Recently, L-carnitine supplementation was found to diminish interleukins levels in aspartame induced toxicity in rats (HAMZA et al., 2019). In the same context, EL-SHERBINI et al. (2017) attributed the protective role of L-carnitine against lead toxicity to ROS production attenuation and free radical scavenging activities via augmentation of antioxidant enzymes. Also, FATEN et al. (2013) suggested the protective activity of L-carnitine against methotrexate-induced oxidative insult via improvement of hepatic GSH levels, and enzymatic antioxidant activities. A recent study showed the antioxidative activity of L-carnitine in streptozotocin-induced diabetic rats through the inducement of antioxidants, GSH, CAT, GPX, and SOD, and by decreasing MDA production (SAMIR et al., 2018). Upregulation of the Nrf2 pathway was conducted through L-carnitine treatment, indicating its crucial role in $\mathrm{H}_{2} \mathrm{O}_{2}$-induced oxidative stress (WANG et al., 2017). L-carnitine may produce evanescent ROS within the cells which may be incriminated in ROS-activated Nrf2 induction (ZAMBRANO et al., 2013). Interestingly, a recent study recorded that acetyl-1-carnitine serves as an Nrf2 inducer, preventing the oxidative stress in lenses (LIU et al., 2017). In the same context, YANG et al. (2015) reported that acetyl-1-carnitine suppressed ROS production and cell death in vitro, by activation of CAT, GPX, SOD, and GSH gene expression via the Nrf2/Keap1 pathway.

It was concluded that L-carnitine plays a pivotal role in the induction of $\mathrm{Nrf2}$, and down-regulation of pro-inflammatory cytokine expressions reflected the activation of antioxidative enzymes and GSH, and suppression of oxidative stress, which is the principal hepatoprotective activity of L-carnitine against BSA-induced liver toxicity, besides improvement of lipid metabolism.

\section{Conflicts of interest}

The authors declare that they have no conflict of interest.

\section{References}

ABDEL-WAHAB, W. M (2014): Thymoquinone attenuates toxicity and oxidative stress induced by bisphenol $\mathrm{A}$ in liver of male rats. Pak. J. Biol Sci. 17, 1152-1160.

DOI: 10.3923/pjbs.2014.1152.1160

ABDEL SAMIE, H. A., S. A. NASSAR, Y. HUSSEIN (2017): Ameliorative Potential of Selenium against Bisphenol A-Induced Hepatotoxicity in Rats. Eygpt. J. Hospt. Med. 67, 444-454.

DOI: $10.12816 / 0036660$

ABEI, H (1984): Catalase in vitro. Methods Enzymol. 105, 121-126.

DOI: 10.1016/S0076-6879(84)05016-3

AL-RASHEED, N. M., L. M. FADDA, H. M. ALI, N. A. ABDEL BAKY, N. F. EL-ORABI, N. M. AL-RASHEED, H. I. YACOUB (2016): New mechanism in the modulation of carbon tetrachloride hepatotoxicity in rats using different natural antioxidants. Toxicol. Mech. Method. 26, 243-250. DOI: $10.3109 / 15376516.2016 .1159769$

ALEISA, A. M., A. A. AL-MAJED, A. A. AL-YAHYA, S. S. AL-REJAIE, S. A. BAKHEET, O. A. AL-SHABANAH, M. M. SAYED-AHMED (2008): Reversal of cisplatininduced carnitine deficiency and energy starvation by propionyl- 1-carnitine in rat kidney tissues. Clin. Exp. Pharm. Physiol. 34, 1252-1259.

DOI: $10.1111 / \mathrm{j} .1440-1681.2007 .04714 . \mathrm{x}$

ANNADURAI, T., S. VIGNESHWARI, R. THIRUKUMARAN, A. P. THOMAS, P. GERALDINE (2011): Acetyl-1-carnitine prevents carbon tetrachloride- 
induced oxidative stress in various tissues of Wistar rats. J. Physiol. Bioch. 67, 519-530.

DOI: $10.1007 / \mathrm{s} 13105-011-0097-\mathrm{z}$

BABBAR, N., R. A. CASERO (2006): Tumor necrosis factoralpha increases reactive oxygen species by inducing spermine oxidase in human lung epithelial cells: a potential mechanism for inflammation-induced carcinogenesis. Cancer Res. 66, 11125-11130.

DOI: $10.1158 / 0008-5472 . C A N-06-3174$

BODAGHI-NAMILEH, V., M. R. SEPAND, A. OMIDI, M. AGHSAMI, S. A. SEYEDNEJAD, S. KASIRZADEH, O. SABZEVARI (2018): Acetyl-1-carnitine attenuates arsenicinduced liver injury by abrogation of mitochondrial dysfunction, inflammation, and apoptosis in rats. Environ. Toxicol. Pharmacol. 58, 11-20.

DOI 10.1016/j.etap.2017.12.005

CAYIR, K., A. KARADENIZ, A. YILDIRIM, Y. KALKAN, A. KARAKOC, M. KELES, S. B. TEKIN (2009): Protective effect of L-carnitine against cisplatin-induced liver and kidney oxidant injury in rats. Cent. Eur. J. Med. 4, 184-191. DOI: 10.2478/s11536-009-0021-x

CHANG, B., M. NISHIKAWA, S. NISHIGUCHI, M. INOUE (2005): L-carnitine inhibits hepatocarcinogenesis via protection of mitochondria. Int. J. Cancer. 113, 719-729. DOI:10.1002/ijc.20636

CULLING, C. F. A., R. T. ALLISON, W. T. BARR (1985): Cellular Pathology Technique. London, Butterworths -Heinemann.

DONG, W., P. P. SIMEONOVA, R. GALLUCCI, J. MATHESON, L. FLOOD, S. WANG, A. HUBBS, M. I. LUSTER (1998): Toxic metals stimulate inflammatory cytokines in hepatocytes through oxidative stress mechanisms. Toxicol. Appl. Pharmacol. 151, 359-366. DOI: $10.1006 /$ taap.1998.8481

EID, J. I., S. M. EISSA, A. A. EL-GHOR (2015): Bisphenol A induces oxidative stress and DNA damage in hepatic tissue of female rat offspring. J. Basic Appl. Zool. 71, 10-19. DOI: 10.1016/j.jobaz.2015.01.006

EL-SHERBINI, E.-S., G. EL-SAYED, R. EL SHOTORY, N. GHEITH, M. ABOU-ALSOUD, S. M. HARAKEH, G. I. KARROUF (2017): Ameliorative effects of 1-carnitine on rats raised on a diet supplemented with lead acetate. Saud. J. Biol. Sci. 24, 1410-1417.

DOI: $10.1016 /$ j.sjbs.2016.08.010

EZEONU, F. C., C. E. OGUAZU, K. I. UBAOJI, B. ANAJEKWU (2015): Bisphenol a causes blood electrolyte imbalance and upsets kidney functions in albino wistar rats. J. Pharm. Sci. Bioscientific. Res. 5, 547-550.

FATEN, R. A., A. E. IBRAHIM, A. E. KHALED (2013): Protective and modulatory effects of curcumin and L-carnitine against methotrexate-induced oxidative stress in albino rats. Res. J. Pharm. Biol. Chem. Sci. 4, 744-754.

GIANNINI, E. G., R. TESTA, V. SAVARINO (2005): Liver enzyme alteration: a guide for clinicians. Canad. Med. Ass. J. 172, 367-379.

DOI:10.1503/cmaj.1040752
HASSAN, Z. K., M. A. ELOBEID, P. VIRK, S. A. OMER, M. ELAMIN, M. H. DAGHESTANI, E. M. ALOLAYAN (2012): Bisphenol A induces hepatotoxicity through oxidative stress in rat model. Oxid. Med. Cell. Long. 2012, 194829.

DOI 10.1155/2012/194829

HAMZA, R. Z., R. A. AL-EISA, A. E. MEHANA, N. S. ELSHENWAY (2019): Effect of L-carnitine on aspartame induced oxidative stress, histopathological changes, and genotoxicity in liver of male rats. J. Basic. Clin. Physiol. Pharmacol. 30, 219-232

DOI 10.1515/jbcpp-2018-0064

HOFF, J., L. V. RLAGT (2000): Methods of blood collection in the mouse. Lab. Animals. 29, 47-53.

HUC, L., A. LEMARIE, F. GUERAUD, C. HELIESTOUSSAINT (2012): Low concentrations of bisphenol A induce lipid accumulation mediated by the production of reactive oxygen species in the mitochondria of HepG2 cells. Toxicol. In Vitro 26, 709-917.

DOI 10.1016/j.tiv.2012.03.017

KABUTO, H., M. AMAKAWA, T. SHISHIBORI (2004): Exposure to bisphenol A during embryonic/fetal life and infancy increases oxidative injury and causes underdevelopment of the brain and testis in mice. Life Sci. 74, 2931-2940.

DOI:10.1016/j.lfs.2003.07.060

KAKKAR, P., B. DAS, P. VISWANATHAN (1984): A modified method for assay of superoxide dismutase. Ind. J. Bioch. Biophys. 21, 131-132.

KAMEL, A. H., M. A. FOAUD, H. M. MOUSSA (2018): The adverse effects of bisphenol A on male albino rats. J. Basic. Appl. Zool. 79, 6.

DOI: 10.1186/s41936-018-0015-9

KAZEMI, S., S. N. MOUSAVI KANI, L. REZAZADEH, M. POURAMIR, M. GHASEMI-KASMAN, A. A. MOGHADAMNIA (2017): Low dose administration of Bisphenol A induces liver toxicity in adult rats. Bioch. Biophys. Res. Commun. 494, 107-112.

DOI 10.1016/j.bbrc.2017.10.074

KESKIN, E., D. ULUISIK, M. ALTIn (2015): Antioxidant effect of L-carnitine in rats fed cholesterol rich diet. Animal. Vet. Sci. 3, 113-116.

DOI 10.11648/j.avs.20150304.13

KORACEVIC, D., G. KORACEVIC, V. DJORDJEVIC, S. ANDREJEVIC, V. COSIC (2001): Method for the measurement of antioxidant activity in human fluids. J. Clin. Pathol. 54, 356-361.

DOI: $10.1136 /$ jep.54.5.356

KORKMAZ, A., M. A. AHBAB, D. KOLANKAYA, N. BARLAS (2010): Influence of vitamin C on bisphenol A, nonylphenol and octylphenol induced oxidative damages in liver of male rats. Food Chem. Toxicol. 48, 2865-2871. DOI 10.1016/j.fct.2010.07.019 
LIU, X. F., J. L. HAO, T. XIE, T. H. MALIK, C. B. LU, C. LIU, C. SHU, C. W. LU, D. D. ZHOU (2017): Nrf2 as a target for prevention of age-related and diabetic cataracts by against oxidative stress. Aging Cell 16, 934-942.

DOI 10.1111/acel.12645

MALAGUARNERA, M., M. P. GARGANTE, C. RUSSO, T. ANTIC, M. VACANTE, M. MALAGUARNERA, T. AVITABILE, G. LI VOLTI, F. GALVANO (2010): L-Carnitine supplementation to diet: a new tool in treatment of nonalcoholic steatohepatitis: a randomized and controlled clinical trial. Am. J. Gastroenterol. 105, 1338-1345.

DOI 10.1038/ajg.2009.719

MANSOUR, H. H (2006): Protective role of carnitine ester against radiation-induced oxidative stress in rats. Pharmacol Res. 54, 165-171.

DOI: $10.1016 /$ j.phrs.2006.04.003

MARMUGI, A., S. DUCHEIX, F. LASSERRE, A. POLIZZI, A. PARIS, N. PRIYMENKO, J. BERTRAND-MICHEL, T. PINEAU, H. GUILLOU, P. G. MARTIN, L. MSELLILAKHAL (2012): Low doses of bisphenol a induce gene expression related to lipid synthesis and trigger triglyceride accumulation in adult mouse liver. Hepatology 55, 395-407. DOI 10.1002/hep. 24685

MARTELLA, A., C. SILVESTRI, F. MARADONNA, G. GIOACCHINI, M. ALLARA, G. RADAELLI, D. R. OVERBY, V. DI MARZO, O. CARNEVALI (2016): Bisphenol A induces fatty liver by an endocannabinoidmediated positive feedback loop. Endocrinol. 157, 1751-1763. DOI 10.1210/en.2015-1384

MOGHADDAM, H. S., S. SAMARGHANDIAN, T. FARKHONDEH (2015): Effect of bisphenol A on blood glucose, lipid profile and oxidative stress indices in adult male mice. Toxicol. Mech. Method. 25, 507-513.

DOI 10.3109/15376516.2015.1056395

MOHAMMADI, H., M. DJALALI, M. DANESHPAZHOOH, N. M. HONARVAR, C. CHAMS-DAVATCHI, F. SEPANDAR, Z. FAKHRI, E. YAGHUBI, M. ZAREI, M. H. JAVANBAKHT (2018): Effects of L-carnitine supplementation on biomarkers of oxidative stress, antioxidant capacity and lipid profile, in patients with pemphigus vulgaris: a randomized, double-blind, placebocontrolled trial. Eur. J. Clin. Nutr. 72, 99-104.

DOI 10.1038/ejen.2017.131

MOON, M. K., M. J. KIM, I. K. JUNG, Y. D. KOO, H. Y. ANN, K. J. LEE, S. H. KIM, Y. C. YOON, B. J. CHO, K. S. PARK, H. C. JANG, Y. J. PARK (2012): Bisphenol A impairs mitochondrial function in the liver at doses below the no observed adverse effect level. J. Korean. Med. Sci. 27, 644-652.

DOI: $10.3346 / \mathrm{jkms} .2012 .27 .6 .644$

OHKAWA, H., N. OHISHI, K. YAGI (1979): Assay for lipid peroxides in animal tissues by thiobarbituric acid reaction. Anal. Biochem. 95, 351-358.

DOI: 10.1016/0003-2697(79)90738-3
PAGLIA, D. E., W. V. VALENTINE (1967): Studies on the quantitative and qualitative characterization of erythrocyte glutathione peroxidase. J. Lab. Clin. Med. 70, 158-169.

PALA, R., E. GENC, M. TUZCU, C. ORHAN, N. SAHIN, B. ER, V. CINAR, K. SAHIN (2018): L-Carnitine supplementation increases expression of PPAR-g and glucose transporters in skeletal muscle of chronically and acutely exercised rats. Cell. Mol. Biol. (Noisy-le-Grand, France) 64, 1-6.

DOI $10.14715 / \mathrm{cmb} / 2018.64 .1 .1$

SAMIR, S. M., A. M. ABBAS, S. M. SAFWAT, H. G. ELSEROUGY (2018): Effect of L-carnitine on diabetesinduced changes of skeletal muscles in rats. J. Basic. Clin. Physiol. Pharmacol. 29, 47-59.

DOI 10.1515/jbcpp-2016-0185

SEDLAK, J., R. H. LINDSAY (1968): Estimation of total, protein-bound, and nonprotein sulfhydryl groups in tissue with Ellman's reagent. Anal. Biochem. 25, 192-205.

DOI: 10.1016/0003-2697(68)90092-4

SUTHAR, H., R. J. VERMA, S. PATEL, Y. T. JASRAI (2014): Green tea potentially ameliorates bisphenol A-induced oxidative stress: An in vitro and in silico study. Biochem. Res. Int. 2014.

DOI: $10.1155 / 2014 / 259763$

TALSNESS, C. E., A. J. M. ANDRADE, S. N. KURIYAMA, J. A. TAYLOR, F. S. VOM SAAL (2009): Components of plastic: experimental studies in animals and relevance for human health. Philos. Trans. R. Soc. Lond. B Biol. Sci. 364, 2079-2096.

DOI 10.1098/rstb.2008.0281

TOUSSON, E., Z. T. ZAKI, W. A. ABU-SHAEIR, H. HASSAN (2014): Methotrexate-induced Hepatic and Renal Toxicity: Role of L-carnitine in Treatment. Biomed. Biotechnol. 2, 85-92.

DOI: $10.12691 / \mathrm{bb}-2-4-4$

THANGASAMY, T., P. JEYAKUMAR, S. SITTADJODY, A. G. JOYEE, P. CHINNAKANNU (2009): L-Carnitine mediates protection against DNA damage in lymphocytes of aged rats. Biogerontology 10, 163-172.

DOI 10.1007/s10522-008-9159-1

VAHDATI HASSANI, F., S. MEHRI, K. ABNOUS, R. BIRNER-GRUENBERGER， H. HOSSEINZADEH (2017): Protective effect of crocin on BPA-induced liver toxicity in rats through inhibition of oxidative stress and downregulation of MAPK and MAPKAP signaling pathway and miRNA-122 expression. Food Chem. Toxicol. 107, 395-405.

DOI 10.1016/j.fct.2017.07.007

VANDENBERG, L.N., M. V.MAFFINI, C. SONNENSCHEIN, B. S. RUBIN, A. M. SOTO (2009): Bisphenol-A and the great divide: a review of controversies in the field of endocrine disruption. Endocr. Rev 30, 75-95.

DOI 10.1210/er.2008-0021

VÖLKEL, W., T. COLNOT, G. A. CSANÁDY, J. G. FILSER, W. DEKANT (2002): Metabolism and kinetics of bisphenol 
a in humans at low doses following oral administration. Chem. Res. Toxicol. 15, 1281-1287.

WAHBY, M. M., Z. M. ABDALLAH, H. M. ABDOU, M. I. YOUSEF, A. S. A. NEWAIRY (2017): Mitigating potential of Ginkgo biloba extract and melatonin against hepatic and nephrotoxicity induced by Bisphenol A in male rats. Egypt. J. Basic. Appl. Sci. 4, 350-357.

DOI: 10.1016/j.ejbas.2017.04.004

WANG, Q., X. JU, Y. CHEN, X. DONG, S. LUO, H. LIU, D. ZHANG (2017): L-carnitine exerts a cytoprotective effect against $\mathrm{H}_{2} \mathrm{O}_{2}$-induced oxidative stress in the fathead minnow muscle cell line. Aquac. Res. 48, 941-954.

DOI: $10.1111 /$ are. 12937

WEINHOUSE, C., O. S. ANDERSON, I. L. BERGIN, D. J. VANDENBERGH, J. P. GYEKIS, M. A. DINGMAN, J. YANG, D. C. DOLINOY (2014): Dose-dependent incidence of hepatic tumors in adult mice following perinatal exposure to bisphenol A. Environ. Health Perspect. 122, 485-491.

DOI 10.1289/ehp.1307449

WILLIAMSON, T. P., D. A. JOHNSON, J. A. JOHNSON (2012): Activation of the Nrf2-ARE pathway by siRNA knockdown of Keap1 reduces oxidative stress and provides partial protection from MPTP-mediated neurotoxicity. Neurotoxicol. 33, 272-279.

DOI 10.1016/j.neuro.2012.01.015

YANG, S. P., X. Z. YANG, G. P. CAO (2015): Acetyl-1carnitine prevents homocysteine-induced suppression of Nrf2/Keap1 mediated antioxidation in human lens epithelial cells. Mol. Med. Rep. 12, 1145-1150.

DOI 10.3892/mmr.2015.3490

YILDIZ, N., N. BARLAS (2013): Hepatic and renal functions in growing male rats after bisphenol $\mathrm{A}$ and octylphenol exposure. Hum. Exp. Toxicol. 32, 675-686.

DOI 10.1177/0960327112464796

YOUSEFINEJAD A, S. F., M. H. JAVANBAKHT, H. MOHAMMADI, E. GHAEDI, M. ZAREI, E. DJALALI, M. DJALALI (2018): Effect of Genistein and L-carnitine and their combination on lipid profile and inflammatory cytokines in experimental nephrotic syndrome. Rep. Biochem. Mol. Biol. 7, 1-8.

YOUSEFINEJAD, A., F. SIASSI, A. MIRSHAFIEY, M. R. ESHRAGHIAN, F. KOOHDANI, M. H. JAVANBAKHT, R. SEDAGHAT, A. RAMEZANI, M. ZAREI, M. DJALALI (2015): Effect of Genistein and L-Carnitine and their combination on gene expression of hepatocyte hmgcoa reductase and ldl receptor in experimental nephrotic syndrome. Iran. J. Public Health 44, 1339-4137.

ZAMBRANO, S., A. J. BLANCA, M. V. RUIZ-ARMENTA, J. L. MIGUEL-CARRASCO, E. REVILLA, C. SANTAMARÍA, A. MATE, C. M. VáZQUEZ (2013): The renoprotective effect of 1-carnitine in hypertensive rats is mediated by modulation of oxidative stress-related gene expression. Eur. J. Nutr. 52, 1649-1659.

DOI 10.1007/s00394-012-0470-x.

Received: 29 July 2018

Accepted: 6 July 2019

\section{LEBDA, M. A., A. S. HASHEM, N. M. TAHA, A. E.-W. MANDOUR, H. A. EDRES: L-karnitin ublažava hepatotoksičnost bisfenola A aktiviranjem Nrf2 i inhibicijom proupalne ekspresije gena citokina u štakora. Vet. arhiv 90, 57-68, 2020.}

\section{SAŽETAK}

Bisfenol, koji se koristi u mnogim industrijama polikarbonatne plastike i epoksidnih smola, ima toksične učinke na organe sisavaca. Mehanizmi na kojima se temelji toksičnost bisfenola dobro su razumljivi, međutim učinci L-karnitina na kemoprevenciju još nisu zabilježeni. Cilj ovog ispitivanja bio je istražiti zaštitni mehanizam L-karnitina protiv hepatotoksičnosti izazvane BPA-om. Mužjaci štakora slučajnim su odabirom podijeljeni u su u 4 skupine od po 10 štakora: kontrolna skupina ( $5 \mathrm{~mL}$ kukuruznog ulja/kg tjelesne težine), duga skupina ( $50 \mathrm{mg}$ bisfenol $/ \mathrm{kg}$ tjelesne težine peroralno), teća skupina (500 mg L-karnitin/kg tjelesne težine i/p) i četvrta skupina (L-karnitin apliciran skupini prethodno tretiranoj bisfenolom). Bisfenol je otopljen u kukuruznom ulju kojim su štakori hranjeni 70 uzastopnih dana. Nakon primjene bisfenola zabilježeno je povećanje mRNK transkripta za stvarnje faktora tumorske nekroze i interleukina 6 uz supresiju nukleotidnog faktora sličnog eritroidu 2, povezanog s faktorom 2. Nakon toga bisfenol je izazvao oksidativni stres i oslabio antioksidativne molekule. Naposljetku, disfunkcija jetre procjenjivana je povišenim razinama aminotransferaza u serumu, alkalne fosfataze, laktat dehidrogenaze, aktivnosti glutamiltransferaze i amonijaka, uz naknadno smanjenje koncentracije serumskog albumina, što je potvrdilo infiltraciju upalnih stanica i hidropičnu degeneraciju, te narušavanje lipidnog statusa. Zanimljivo je da je istodobna primjena L-karnitina poboljšala funkciju jetre i lipidni status, što je objašnjeno aktivacijom transkripta mRNK tipa 2 povezanog s faktorom 2, koji je povećao razine antioksidansa i potisnuo oksidativni stres, te ekspresiju gena faktora tumorske nekroze i interleukina 6. Zaključno, L-karnitin je pokazao hepatozaštitnu aktivnost protiv toksičnosti bisfenola antioksidativnim i protuupalnim učincima.

Ključne riječi: bisfenol A, L-karnitin, proupalni citokini, hidropsna degeneracija, oksidacijski stres 